\title{
A system to optimize fish production: a case study of semi-intensive Colossoma macropomum (Osteichthyes, Serrasalmidae) aquaculture
}

\author{
Joaquim Craveiro ${ }^{1}$, Mario Salvatierra ${ }^{2}$, Gustavo Silva Neto ${ }^{3}$, Karla Tribuzy $^{4}$ \& Carlos Freitas $^{1}$ \\ ${ }^{1}$ Federal University of Amazonas, Faculty of Agricultural Sciences \\ Department Fisheries Sciences, Manaus, AM, Brazil \\ ${ }^{2}$ Federal University of Amazonas, I Comp, Manaus, AM, Brazil \\ ${ }^{3}$ Federal University of Amazonas, DEMEC, Manaus, AM, Brazil \\ ${ }^{4}$ Federal University of Amazonas, ICE, Manaus, AM, Brazil \\ Corresponding author: Joaquim Craveiro (jgabael26@gmail.com)
}

\begin{abstract}
Aquaculture is a fast growth activity in the world, but needs continued improvement in the conduct of management. In this sense, we highlight the Amazon basin, which has important species of fish as Colossoma macropomum with incipient production to meet the demand of the consumer market. Since that problem identified, we applied a Markovian decision process aiming to develop an optimization system to maximize the yield of the $C$. macropomum aquaculture. Were used mathematical algorithms were simulated with layout scenarios with 5 and 10 ponds, representing different size aquaculture farms. The transition between the growth phases was considered a stochastic process to satisfy the Markov property as per a sequential queuing through growth phases. The main goal was to define the target weight mix for the market and their optimal levels that optimize the production. The highest profitabilities were US\$9,608 and 15,385 for 5 and 10 ponds layout scenarios, respectively, with a target weight mix harvest of $0.5 \mathrm{~kg}$ and $1 \mathrm{~kg} ; 0.5 \mathrm{~kg}, 1 \mathrm{~kg}$ and $2 \mathrm{~kg}$, respectively. The results showed the number of months for discounted the fixed monthly cost, about the cycle time that lasted of 5, 7 and 11 months, as well as the optimization was defined with the time at the fingerlings stage fixed for 50 days, possible to be improved.
\end{abstract}

Keywords: Markovian decision; stochastic process; fish farming; economic performance

\section{INTRODUCTION}

World aquaculture has been developing with the exploration of several species and employing diversified processes of production (FAO, 2014). Two distinct subsectors can be outlined: the first one includes commercial farms, which primarily use intensive and super-intensive layouts to produce medium and high value-added goods for regional or global markets. The second one includes small farmers with extensive and semi-intensive practices, farming low-value species for the household subsistence or local markets. These small farmers are subject to severe constraints in the planning and management which negatively impact their yield, as such restrictions on the cost of production vis-à-vis time, among which the following could be highlighted: i) quantity of fish feed needed, ii) frequency of input of fingerling, iii) fattening cycle, iv) batch size and v) ideal weight for the market with a harvest that will maximize the profit for the investment (Bjørndal et al., 2004).

Some methodologies have been proposed to improve the management system through the use of operational research (OR) and queueing theory (QT), both already implemented in industrial processes (Banks, 1998; Law \& Kelton, 2000; Bjørndal et al., 2004; Hernández et al., 2007). These methods are based on mathematical models and computer algorithms and are able to provide viable solutions for planning in agricultural processes (Pidd, 1992; Knill, 1994; Silveira et al., 2013). Some of them assume the premise that ponds describe a sequence of queuing worked as Markov process, with the time of fish growth a stochastic event described as a discrete time-variable

Corresponding editor: Erich Rudolph 
(Sparre, 1976; Winston, 2004; Summerfelt et al., 2009; Halachmi, 2012).

The aquaculture performed at the Amazon basin is predominantly made of small farmers that use semiintensive systems. These small farmers are owners of low capital, who use production system is based on empirical knowledge. This study, therefore, developed an optimum weight mix of fish produced that maximize the production of Colossoma macropomum, the fish species most produced at the Amazon basin. A mathematical algorithm obtained the optimum weight mix based on the zootechnical, operational and economic information.

\section{MATERIALS AND METHODS}

\section{Zootechnical data}

Zootechnical data were gathered in the Ecology Pescado Farm, located on the Highway AM 010, km 127, municipality of Rio Preto da Eva (Amazonas, Brazil). The Measurements of production ware based on three semesters of farming, from April 2014 until November 2015, and included two stages of growth: fingerlings and fattening. Initially, the fingerlings were 1.5 and $2.0 \mathrm{~g}$, separated into two batches of 19,200 fishes, daily nourished with commercial feed (32\% of protein) at the proportion of $5 \%$ of the total biomass. This stage was denominated of Stage I, the fingerlings stayed until time 50 days of duration of growth. After that, the batches were distributed in equal parts by (in) eight ponds of fattening, denominated as Stage II, nourished with commercial feed with $28 \%$ raw protein at $3 \%$ of the biomass, with a total harvest after 100 days. These ponds featured a standardized area of 3,200 $\mathrm{m}^{2}$ and $1.5 \mathrm{~m}$ deep. Based on the real situation, layout scenarios of designed ponds were defined to maintain biomass under the availability of dissolved oxygen (DO). The feeding management and the control of physical and chemical parameters of the water were registered in each step (Goulding \& Carvalho, 1982; Kubitza \& Kubitza, 2000; Izel \& Melo, 2004; Cavero et al., 2009; Gomes \& Silva, 2009). The time that the fish remained in each growth stage complied with the methodology described by Halachmi (2007) for a system with recirculation in aquaculture (RAS), and will be demonstrated in the result.

Tambaqui (Colossoma macropomum Cuvier, 1818) is a fish of the order of Characiformes, belonging to the family Serrasalmidae (Géry, 1977; Mirande, 2010) and native of the Amazon and Orinoco Basins. These native species are harvested in Brazil and some Latin American countries due to its good zootechnical qualities. (Goulding \& Carvalho, 1982; Saint-Paul,
1986; Graef, 1995; Sousa \& Freitas, 2010; Barros \& Martins, 2012).

The economic assessment was adopted following the methodology proposed by Silva et al. (2003), and just the partial operational cost (POC), defined as the amount spent with fish feed and fingerlings, wages, energy, and maintenance, was considered. It includes the depreciation per pond, within 15 years, and a gross revenue (GR) earned with the sale of live fish (in nature) at the production site, to obtain the partial net profit (exchange: US $\$ 1.00=\mathrm{R} \$ 3.72$, Brazil on January 15, 2019).

\section{Conceptualizing the system of fish batch queueing for simulation}

Assuming that the fish length follows a regular distribution with a constant coefficient of variance during the entire period of growth, and its distribution of size is discrete, it was assumed the fish growth is a stochastic variable over time, which complies with the property of Markovian process, meaning that, its future state depends solely on its current state (Summerfelt et al., 1993; Forsberg, 1996; Halachmi, 2012; Tirdad et al., 2016). The transition from one stage to the next was simulated, describing a sequential queueing through the growth stages, with features of a dynamic process (Knill, 1994; Cozman, 2000, 2005; Jacoby et al., 2012). The time was taken as a linear measure through which the system moves. Thus, when a fish batch or entity grows to its predetermined size, it moves to the next stage (Fig. 1). At the end of each growth stage a batch was divided, for the fish to initiate with a weight corresponding to the lesser biomass until it attains its limit at each successive stage.

The species growth function was employed to estimate the weight of an individual in a series of transitions between the fingerlings stage $t_{0}$ and the fattening stage $t_{1}$ until it reaches the optimum weight for harvesting. In our model, the premise had been to attend the market demands and to produce fishes with $0.5 \mathrm{~kg}, 1 \mathrm{~kg}$ and $2 \mathrm{~kg}$ average weight for cold stores, supermarkets and street fairs, respectively. The consumption of fish feed was proportional with the food conversion rate, corresponding to each weight defined in 1:1, 1.2:1, and 1.6:1, following the actual results obtained at Ecology Pescado Farm.

\section{Formulation of the fish batch queueing}

The fish farming was modeled as a Markovian process (Howard, 1960; Bonet \& Geffner, 2005), assuming that environment is completely observable and that the best strategy can be taken by knowing just the current state of the agent (Puterman, 1994; Jacoby et al., 2012; Liu $\& \mathrm{Yu}, 2016$ ). The time (in days), represented by expec- 


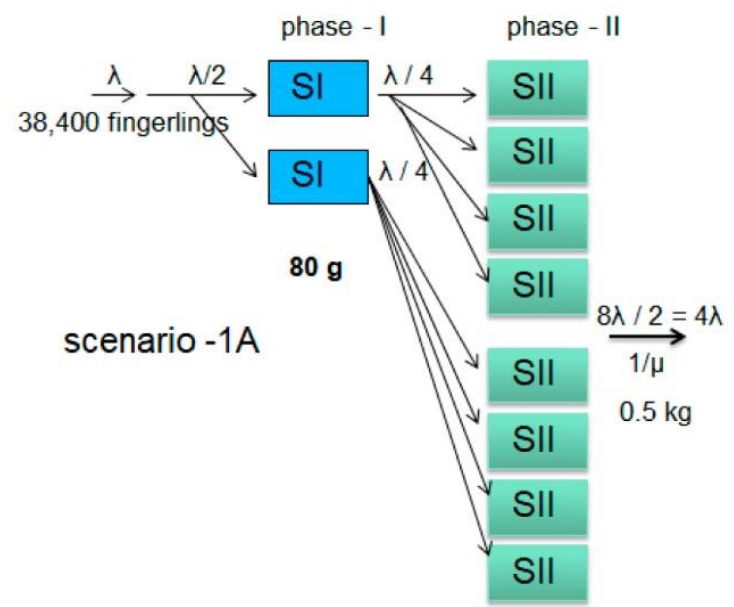

Figure 1. Scenario 1A, where $\lambda$ represents the number of fish going through the initial growth in Phase I: fingerlings, and the rate of departure to Phase II: fattening. SI is the time spent waiting for a fish in an $i^{\text {th }}$ growth stage.

tation $\mathrm{E}(\mathrm{S})$ of each growth stage during the production cycle, was estimated (Halachmi, 2007), where $S$ is the controlled environment for fish farming. The arrival of fish batches into the system $\lambda$ was assumed to follow a Poisson distribution (likelihood of the occurrence of an event in a specified interval) and the output at the harvest given by $\mu$ following an exponential distribution (a continuing random variable of non-negative values) (Krajewsky et al., 2009; Corrêa \& Corrêa, 2012; Haji \& Ross, 2015), where the use of the pond is $100 \%$ obtained when $\rho=\lambda / \mu=1$. It's possible, thus, establish in the model a balance between production batch of fish, during internship of fingerlings batch input arriving in the system equal or close to its output $\lambda=\mu$ that is:

$$
\mathrm{E}(\mathrm{S})=1 / \mu=1 / \lambda
$$

With the composition of several semi-dug ponds in the farm and input equal to output in each pond, the scenario 1B (Fig. 2) was performed to define the strategy that optimize the management or to obtain the optimum $\lambda$ for a queuing system with transitions between the growth stages, as described by the equation (1).

Given the number of parts in which a fish batch is divided $(\mathrm{P})$ and the number of dug ponds (c) in a growth stage, the equation becomes:

$$
\rho=(\lambda / \mu \times \mathrm{P} / \mathrm{c})
$$

Assuming $\rho=1$ to represent full pond use:

$$
1 / \mu=(1 / \lambda \times c / P)
$$

Taken $\mathrm{S}$ as the expected time that a fish spends in an growth stage, which is estimated as $S=(1 / \mu)$, it's possible to write that:

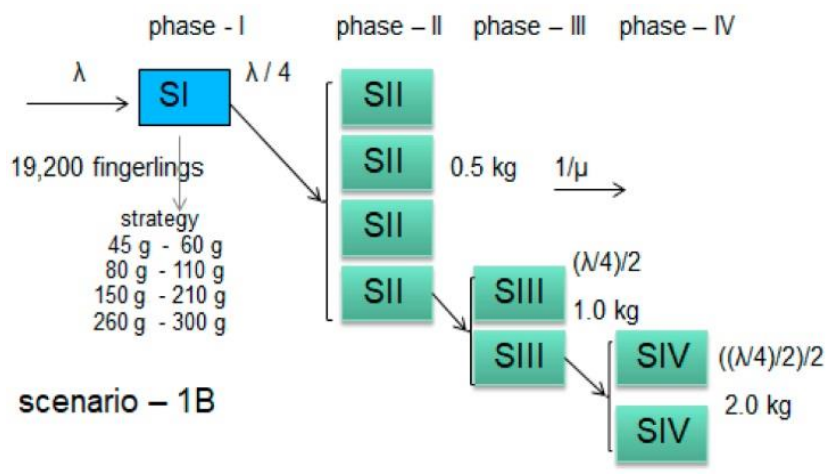

Figure 2. Scenario 1B, with a '1, 4, 2, 2 layout'. Where $\lambda$ represents fingerlings batch input into the system, going through the Phase I, and the departure rates to fattening Phase II, III and IV. SI is the expected amount of time spent on one fish in the $i^{t h}$ growth stage.

$$
\begin{gathered}
\mathrm{Si}=\left(1 / \lambda \times \mathrm{c}_{\mathrm{i}} / \prod^{\mathrm{i}}{ }_{1} \mathrm{P}_{\mathrm{i}}\right) \\
\mathrm{Si}=1 /\left(\lambda \mathrm{P}_{\mathrm{i}} / \mathrm{c}_{\mathrm{i}}\right)=\mathrm{c}_{\mathrm{i}} /\left(\lambda \mathrm{P}_{\mathrm{i}}\right)
\end{gathered}
$$

where Si: the period in the $i^{\text {th }}$ growth stage, $\mathrm{c}_{\mathrm{i}}$ : the expected number of dug ponds on the $i^{\text {th }}$ growth stage and $\mathrm{P}_{\mathrm{i}}$ : the number of parts into which an $i^{\text {th }}$ fish batch is divided, once fish enter at the $i^{\text {th }}$ growth stage. In our simulation, the batch with $\mathrm{N}_{1}=19,200$ at the Stage I was divided into smaller parts to Stage II, forming four sub-batches with $\mathrm{N}_{2}=4,800$ fish each, and the real number in categories was $\mathrm{P}_{2}=2$.

In general, the full growth period $\Sigma \mathrm{S}_{\mathrm{i}}$ is known and depends on the biological characteristics of the farmed species and the local conditions of the farming system, such as water quality, temperature, oxygen, feeding and management, where:

$$
\begin{aligned}
& \Sigma \mathrm{S}_{\mathrm{i}}=\Sigma\left(1 / \lambda \times \mathrm{c}_{\mathrm{i}} / \prod \mathrm{P}_{\mathrm{i}}\right) \rightarrow \Sigma \mathrm{S}_{\mathrm{i}}=1 / \lambda \Sigma\left(\mathrm{c}_{\mathrm{i}} / \prod \mathrm{P}_{\mathrm{i}}\right) \rightarrow 1 / \lambda= \\
& \Sigma \mathrm{S}_{\mathrm{i}} / \Sigma\left(\mathrm{c}_{\mathrm{i}} / \prod \mathrm{P}_{\mathrm{i}}\right) \\
& \Sigma \mathrm{S}_{\mathrm{i}}=\Sigma\left(\mathrm{c}_{\mathrm{i}} /\left(\lambda \mathrm{P}_{\mathrm{i}}\right)\right) \rightarrow 1 / \lambda=\Sigma \mathrm{S}_{\mathrm{i}} / \Sigma\left(\mathrm{c}_{\mathrm{i}} / \mathrm{P}_{\mathrm{i}}\right)
\end{aligned}
$$

For a forecasted annual business volume, $\mathrm{T}$ (ton per year) could be obtained by:

$$
\mathrm{T}=\lambda \times \mathrm{N}_{\mathrm{f}} \times \mathrm{B}_{\mathrm{f}}=\left(\Sigma\left(\mathrm{c}_{\mathrm{i}} / \prod \mathrm{P}_{\mathrm{i}}\right) / \Sigma \mathrm{S}_{\mathrm{i}}\right) \times \mathrm{N}_{\mathrm{f}} \times \mathrm{B}_{\mathrm{f}}
$$

where $\lambda$ (batches per year) are the input and output rates, $\mathrm{N}_{\mathrm{f}}$ (fish) is the number of fishes in a batch and $\mathrm{B}_{\mathrm{f}}$ $(\mathrm{kg})$ is the final fish weight. Also, the solution to the optimization problem is given by:

$$
\max \mathrm{T}=\max \left(\Sigma\left(\mathrm{c}_{\mathrm{i}} / \prod \mathrm{P}_{\mathrm{i}}\right) / \Sigma \mathrm{S}_{\mathrm{i}}\right) \times \mathrm{N}_{\mathrm{f}} \times \mathrm{B}_{\mathrm{f}}
$$

Subject to the restriction, where $\Sigma \mathrm{c}_{\mathrm{i}}$ : number of dug ponds, which is associated with farm size or available capital; $\mathrm{D}_{\mathrm{i}}$ : density allowed of fish biomass at the end of the growth stage of any $i$, defined by the availability of dissolved oxygen (DO) for fish in the pond, in this study considered as $5 \mathrm{mg} \mathrm{L}^{-1} \mathrm{DO}$.

$$
\Sigma \mathrm{S}_{\mathrm{i}} \leq \text { total growth period at all stages }
$$


$\mathrm{B}_{\mathrm{i}}=\mathrm{B}_{\text {fingerling }}+\mathrm{Gr} \Sigma \mathrm{S}_{\mathrm{i}}$, where fingerlings initial biomass + fish body weight is dependent on the growth rate $\mathrm{Gr}$ and time in the system $\Sigma \mathrm{S}_{\mathrm{i}}$.

$\mathrm{c}_{\mathrm{i}}=\lambda \times \mathrm{S}_{\mathrm{i}} \times \prod^{\mathrm{i}}{ }_{1} \mathrm{P}_{\mathrm{i}}$, number of farming ponds in growth stage i [of Eq. (4)]

The decision parameters rs were in this case: $\mathrm{c}_{1}, \mathrm{c}_{2}$, $c_{3}, c_{4}, S_{1}, S_{2}, S_{3}, S_{4} P_{1}, P_{2}, P_{3}, P_{4}, N, \lambda$.

\section{Criteria for the number of fishes in each batch}

The semi-dug ponds, in this study, were built each one with a volume of $4,800 \mathrm{~m}^{3}(40 \times 80 \times 1.5 \mathrm{~m})$. The breathing rate of the species Colossoma macropomum known to be $250 \mathrm{mgO}_{2} \mathrm{~kg}^{-1} \mathrm{~h}^{-1}$. This datum was used as a parameter in the calculation of the maximum biomass over time: stocking density per availability of DO for the fish in the pond at each growth stage. The increase in the quantity of fish in the environment causes a reduction in DO at a critical level of $3 \mathrm{mg} \mathrm{L}^{-1}$ for the tambaqui species (Fig. 3) (Val \& Almeida-Val, 1995; Gomes et al., 2006).

The mortality rate was $1 \%$ in each pond. The average water temperature in the harvest dug ponds ranged between 28.03 to $29.92^{\circ} \mathrm{C}$. The food management and the control of the physical and chemical parameters of the water followed the recommendation suggested by the literature (Gomes \& Silva, 2009).

Table 1 shows that dissolved oxygen is an important parameter used in the calculation for the planning of the production per pond, which is an important restriction that should be used by the farm management to balance the production flow in the system of semi-dug ponds. At the successive growth stages with the limitation of biomass to $2,400 \mathrm{~kg}$ per pond is demonstrated in the last column $(7,200,000 / 250) / 12=2,400 \mathrm{~kg})$.

Changing in the proportions in $1.5 \mathrm{x}, 2 \mathrm{x}, 2.5 \mathrm{x}$ only in the pond area phase I (fingerlings stage), can allowing as a strategy to transfer fish with an advanced weight in balance time of the system, that is, $1 / \mu=1 / \lambda$, as shown in the volume column.

\section{The optimization model}

The stochastic effect in fish growth, as related to genetic and environmental factors under optimal conditions, is considered as a Markovian process (Sparre, 1976; Leung \& Shang, 1989; Knill, 1994). Integer Linear Programming (ILP) was used for a Linear Programming (LP) problem in which every or some of its variables are discrete having to assume integer values, and Nonlinear Integer Programming (NLIP) when decision variables are quantities of $0.5,1$ and $2 \mathrm{~kg}$ fish. For the simulation, to represent small and

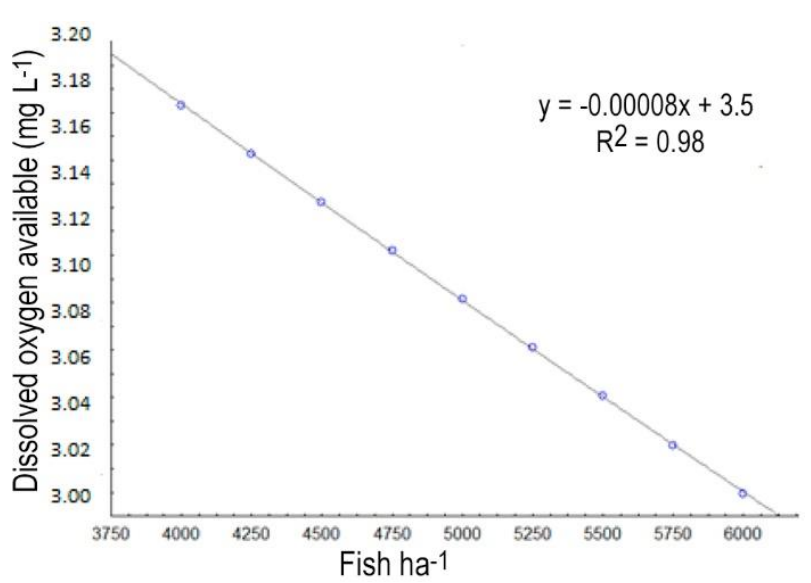

Figure 3. Influence of the quantity of fish (fish ha-1) on the dissolved oxygen available $\left(\mathrm{mg} \mathrm{L}^{-1}\right)$ provided by the equation $y=-0.00008 x+3.5$, the result of the research with tambaqui, where, $y$ : dissolved oxygen, and $x$ : quantity of fish.

large fish farmers, two scenarios of 5 and 10 ponds were formed, respectively.

According to the biology of $C$. macropomum, the growth in weight is reached within the foreseen period, assuming as to the simulation, that a fish batch with a target weight of $0.5 \mathrm{~kg}$ at the end of Stage II, is farmed after 5 months of production, and show a normal distribution, with a constant variation coefficient along the entire growth period (Table 2).

Although higher weighing fish are sold at higher prices, this will result in longer time with the implication of increasing monthly production cost. The fish farmer, therefore, is not capable of defining the best weight mix strategy for the harvest, thus, the need to use an optimization model to solve the problem (Hillier \& Lieberman, 1988; Corrêa \& Corrêa, 2012; Haji \& Ross, 2015). In this study, the computer simulation was written in the academic version of CPLEX Studio124 $\left(\mathrm{IBM}^{\circledR}\right)$ software.

The mathematical algorithm formulated for the simulation analysis is integrally shown in Appendix I concerning a 10-ponds layout. Another algorithm was designed (Appendix II) for 5 pond layout, showing to be commensurate in quantities, and with a premise of harvest in both with 0.5 and $1 \mathrm{~kg}$ and $0.5,1$ and $2 \mathrm{~kg}$ target weight mix with the purpose of optimization in the production of biomass of the tambaqui in the semicut pond.

\section{RESULTS}

\section{Number of days for each growth stage}

Employing equations (4) and (7), we obtained the numerical values for the layout '1, 4, 2, 2', correspon- 
Table 1. Tambaqui maximum biomass through the Dissolved Oxygen (DO) available for fish in the pond.

\begin{tabular}{ccccccccc}
\hline $\begin{array}{c}\text { Volume } \\
\left(\mathrm{m}^{3}\right)\end{array}$ & $\begin{array}{c}\text { Quantity } \\
\text { water per } \\
\text { pond (L) }\end{array}$ & $\begin{array}{c}\text { DO } \\
\left(\mathrm{mg} \mathrm{L}^{-1}\right) \\
\text { for fish }\end{array}$ & $\begin{array}{c}\text { Quantity DO } \\
\text { in }\left(\mathrm{mg} \mathrm{L}^{-1}\right)\end{array}$ & $\begin{array}{c}\% \text { DO } \\
\text { consumption } \\
\text { per pond }\end{array}$ & $\begin{array}{c}\text { Quantity DO } \\
\text { in pond } \\
\text { for fish }\end{array}$ & $\begin{array}{c}\text { Quantity } \\
\text { consumption } \\
\left(\mathrm{mg} \mathrm{DO} \mathrm{kg}^{-1}\right)\end{array}$ & $\begin{array}{c}\text { Period } \\
(\mathrm{h})\end{array}$ & $\begin{array}{c}\text { Biomass } \\
\text { capacity } \\
\left(\mathrm{kg}^{2}\right)\end{array}$ \\
\hline 4,800 & $4,800,000$ & 5 & $24,000,000$ & 70 & $7,200,000$ & 250 & 12 & 2,400 \\
7,200 & $7,200,000$ & 5 & $36,000,000$ & 70 & $10,800,000$ & 250 & 12 & 3,600 \\
9,600 & $9,600,000$ & 5 & $48,000,000$ & 70 & $14,400,000$ & 250 & 12 & 4,800 \\
12,000 & $12,000,000$ & 5 & $60,000,000$ & 70 & $18,000,000$ & 250 & 12 & 6,000 \\
\hline
\end{tabular}

Table 2. Prediction of the time of the growth period to system simulation.

\begin{tabular}{ccc}
\hline $\mathrm{t}_{1}$ & $\mathrm{t}_{2}$ & $\mathrm{t}_{3}$ \\
5 months & 7 months & 11 months \\
\hline $0.5 \mathrm{~kg}$ & $1 \mathrm{~kg}$ & $2 \mathrm{~kg}$ \\
\hline
\end{tabular}

ding to a total tambaqui growth time equal to $\Sigma \mathrm{S}_{\mathrm{i}}=330$ days; with the ponds number of $\mathrm{c}_{1}=1 ; \mathrm{c}_{2}=4 ; \mathrm{c}_{3}=2 ; \mathrm{c}_{4}$ $=2$; the number of sub-batches formed from a batch $\mathrm{P}_{1}$ $=1 ; \mathrm{P}_{2}=2 ; \mathrm{P}_{3}=1 ; \mathrm{P}_{4}=1$ were:

Eq. $7 \rightarrow \quad 1 / \lambda=330 /(1 / 1+4 / 2+2 / 1+2 / 1)=47$ days

Eq. $4 \rightarrow \quad \mathrm{SI}=1 / \lambda \times \mathrm{c}_{\mathrm{i}} / \mathrm{P}_{\mathrm{i}}=47 \times 1 / 1=47$ days

$\mathrm{SII}=1 / \lambda \times \mathrm{c}_{\mathrm{i}} / \mathrm{P}_{\mathrm{i}}=47 \times 4 / 2=94$ days

$\mathrm{SIII}=1 / \lambda \times \mathrm{c}_{\mathrm{i}} / \mathrm{P}_{\mathrm{i}}=47 \times 2 / 1=94$ days

$\mathrm{SIV}=1 / \lambda \times \mathrm{c}_{\mathrm{i}} / \mathrm{P}_{\mathrm{i}}=47 \times 2 / 1=94$ days

In accordance with our measurements for the tambaqui growth (Fig. 2), within the minimum time of 310 days and the maximum of 330 days, after this time, a reduction on the fish production was observed influenced by the time of the overall growth. As per measurements carried out, the overall growth period $\left(\Sigma \mathrm{S}_{\mathrm{i}}\right)$, and the results of the model were calculated with Eqs. (8) and (9). Notice that, for generalization, many ponds and every layout with initial number of fish was of 19,200 , and the number of ponds in each growth stage in '1, 4, 2, 2 layout was $c_{1}=1 ; c_{2}=4 ; c_{3}=2$; and $\mathrm{c}_{4}=2$; and the number of sub-batches formed from a batch: $\mathrm{P}_{1}=1 ; \mathrm{P}_{2}=2 ; \mathrm{P}_{3}=1 ;$ and $\mathrm{P}_{4}=1$.

The optimal values maintain biomass density criterion of $2,400 \mathrm{~kg} \mathrm{~m}^{-3}$ with the layout of several semi-dug ponds in the farm as per 1, 4, 2, 2' layout (Fig. 2 ), a batch of fish with density $\mathrm{D}=19,200$ with a suggestion altering in $2.5 \times$ the fingerlings pond area, a fish can remain in the stage I pond until it reaches biomass capacity through the availability of DO with the $312 \mathrm{~g}$ weight $\left(6,000 \mathrm{~kg} / 19,200 \mathrm{fish}=312 \mathrm{~g}\right.$ fish $\left.^{-1}\right)$, then, transferred to next stages. Warning, the $1 \%$ mortality rate at each stage was not considered in the above calculation. Thus, in this study, the mortality rate adds to $4 \%$. The purchase of fingerlings was increased by a factor of 1.04 corresponding to 768 units to offset the loss during the production cycle.

\section{Simulation and optimization in the production of tambaqui with a target weight mix for the market}

Scenarios with a weighted mix for harvesting were designed bearing in mind the criterion of $2,400 \mathrm{~kg}$ limit of biomass capacity per pond, given the DO restriction. The optimum growth periods, at the end of each stage, suggests moving a fish batch or perform its harvest to the market in compliance with the result obtained by equation (4). In this study, the time was 47, 141, 235, and 330 days, obtaining a fish classification vis-a-vis time (fish age), with a target weight estimated by the growth curve in tambaqui weight (Fig. 4) as defined by the equation $\left.\mathrm{y}=(6950.79) \times\left[1-\exp ^{-(1.18094)} \times \mathrm{x}\right)\right]^{3}$, where " $\mathrm{x}$ " represents the production time, projec-ting fish with an average weight of $0.080,0.487,1.08$, and $2.15 \mathrm{~kg}$. Obtaining the transfer criterion, within 47 days and $0.080 \mathrm{~kg}$, from Stage I to Stage II. To move within 141 days, and $0.487 \mathrm{~kg}$ from Stage II to Stage III, and to move with 235 days and $1.08 \mathrm{~kg}$ from Stage III to Stage IV, from this with 330 days and $2.15 \mathrm{~kg}$.

Based on the results of the balancing of the fish batch queuing system in ponds over time, it is possible to define different criteria of classification for decisionmaking, in the harvest planning management with target weight for the market or forecast for a new project business plan. However, it is necessary to define which scenario with a target weight mix for the market assures the efficiency and the profitability in the production of tambaqui biomass.

The result of the optimization was obtained with the simulation analysis to solve this issue, in accordance with the following premises:

a) The complete cycle tambaqui farming ranges from fingerlings to harvesting, taking into account the multiple production cycles per pond.

b) The time span is divided into a period that includes the growth rates in ponds, as per which the external variables (temperatures, DO, prices, costs) and decision-making variables (harvesting strategies and fish batch input) can be considered as constants, as of 


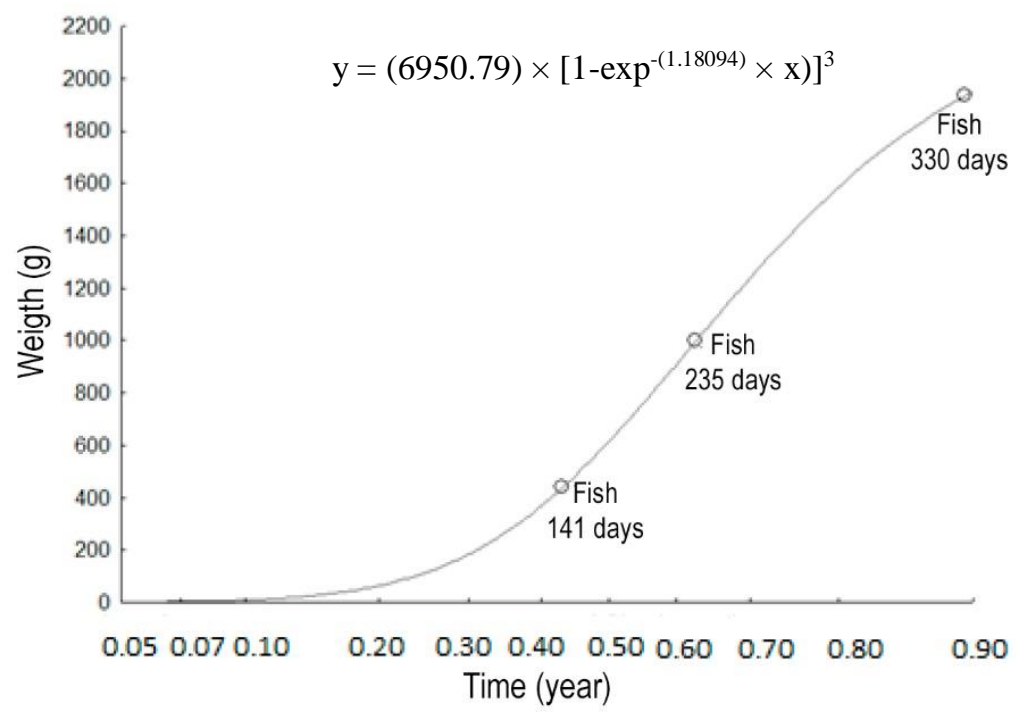

Figure 4. The growth curve in Colossoma macropomum weight, in semi-intensive fish farming, commercial scale, from April 2014 until November 2015. Research data registered from three cycles and 100 samples per total of an experimental unit of six ponds, in the State of Amazonas rural area.

the stabilization of the harvesting process. The results hereby submitted refer to a one-year temporal span distributed in three periods of 5, 7 and 11 months for stages II, III and IV respectively, periods defined as production time.

c) The immediate harvest of the predetermined fraction of the biomass limit in the pond at the end of each stage is considered, the quantity of fish with a weight corresponding to the smallest biomass remaining until its limit at each successive stage is reached.

d) Fish batches with a homogeneous distribution of weight are considered.

e) The prices considered for the simulation are independent of the demand. In this study were US\$ 1.18 $\mathrm{kg}^{-1}$, US\$ $1.48 \mathrm{~kg}^{-1}$ and US\$ $1.93 \mathrm{~kg}^{-1}$ for $0.5 \mathrm{~kg}, 1 \mathrm{~kg}$ and $2 \mathrm{~kg}$ of fish, respectively.

With the mathematical algorithm designed for the simulation analysis of layout scenarios of 10 and 5 ponds, having a premise, the harvest in both, target weight mix with $0.5,1$ and $0.5,1$ and $2 \mathrm{~kg}$ denominated Mix-2 and Mix-3, respectively, and with the objective to optimize the tambaqui biomass production in semidug ponds, maximizing profits. The computer results generated in CPLEX Studio124 (IBM $\left.{ }^{\circledR}\right)$ software; the following possible combinations are shown in Table 3.

\section{Economic assessment}

Regarding the economic assessment, the methodology described by Silva et al. (2003) was followed. Only the partial operational cost (COP), defined as amounts spent on fish feed and fingerlings, wage, power and maintenance, including the depreciation per pond, ware considered. Such costs being deducted from the gross revenue (GR) obtained from the sales of live fishes (in nature) at the production site (Table 4).

\section{DISCUSSION}

The steady demand for production and the increase of the market competition for tambaqui have led fish farmers to the short cycle harvest practice, obtaining $0.5 \mathrm{~kg}$ average fish weight to supply cold stores, resulting in operational margins affecting their profitability. According to Cacho (1997), cost planning exerts a major impact in the cash flow of fish farming undertaking, as well as the allocation of limited production resources such as fish feed, fingerlings, labor, working capital and environmental resources. To Llorente \& Luna (2014), the lack of competition of many agricultural undertakings, is not on technical and biological aspects, but arise from the difficulty in the management of the production process and economic decisions taken. The results presented in this work suggest a mathematical algorithm formulated and simulated with 10 and 5 pond layout scenarios, as showed Appendix I and II, with the harvesting premise in both, with a target weight mix of $0.5 \mathrm{~kg}, 1 \mathrm{~kg}$ and 0.5 $\mathrm{kg}, 1 \mathrm{~kg}$ and $2 \mathrm{~kg}$ over time. The main objective established was to optimize the tambaqui biomass production in semi-dug ponds, maximizing profits and defining the optimal policy to management effectiveness.

The formulated mathematical algorithm with simulation analysis has allowed the identification of a production strategy guiding the fish farmers into taking 
Table 3. Colossoma macropomum biomass production optimization in semi-dug ponds. ${ }^{1}$ Fingerlings stage time - I was fixed in 50 days and is included in the stage - II for simulation (=150 days). ${ }^{2}$ Partial Net Profit was considered jointly with the production time: F-II, F-III, F-IV simulated results.

\begin{tabular}{|c|c|c|c|c|c|c|c|c|}
\hline \multirow{2}{*}{ Variable } & \multicolumn{4}{|c|}{5 ponds (Simulated) } & \multicolumn{4}{|c|}{10 ponds (Simulated) } \\
\hline & F-I & F-II & F-III & F-IV & F-I & F-II & F-III & F-IV \\
\hline Time (days) $^{1}$ & 50 & 100 & 210 & 330 & 50 & 100 & 210 & 330 \\
\hline$N^{o}$ of fish batch ${ }^{-1}$ & 19,200 & 4,800 & 2,400 & 1,200 & 38,400 & 4,800 & 2,400 & 1,200 \\
\hline Final weight stage ${ }^{-1}(\mathrm{~kg})$ & 0.080 & 0.5 & 1.0 & 2.0 & 0.080 & 0.5 & 1.0 & 2.0 \\
\hline Qty harvest sole weight & - & 19,200 & - & - & - & 38,400 & - & - \\
\hline Qty harvest mix-2 & - & 9,600 & 9,600 & - & - & 19,200 & 19,200 & - \\
\hline Qty harvest mix-3 & - & 9,600 & 4,800 & 4,800 & - & 19,200 & 9,600 & 9,600 \\
\hline Sole weight profit (US\$) ${ }^{2}$ & - & $(-949.77)$ & - & - & - & $2,663.13$ & - & - \\
\hline Profit mix-2 (US\$) ${ }^{2}$ & - & \multicolumn{2}{|c|}{$1,610.13-$} & & . & \multicolumn{2}{|c|}{$9,608.04-$} & \\
\hline Profit mix-3 (US\$) ${ }^{2}$ & - & \multicolumn{2}{|c|}{$2,673.46$} & & - & \multicolumn{2}{|c|}{$15,384.84$} & \\
\hline
\end{tabular}

Table 4. Partial operational cost (POC) with the tambaqui biomass production in semi-dug ponds. ${ }^{1} \mathrm{MOD}$ : Labor with wage $($ Brazil = US\$ 233.83) with charges (70\%) being one caretaker for five ponds; and one employee and one caretaker for 10 ponds. ${ }^{2}$ CAA: Apparent food conversion. (Exchange: US $\$ 1.00=\mathrm{R} \$ 3.72$, Brazil on January 15, 2019).

\begin{tabular}{lcrr}
\hline 1. Fixed costs & Unit & 5 ponds & 10 ponds \\
\hline Depreciation of facilities and infrastructure/pond (US\$) & Month & 78.38 & 63.91 \\
Electricity/maintenance and others (US\$) & Month & 370.40 & 370.40 \\
Labor and labor charges (70\% MOD) (US\$) ${ }^{1}$ & Month & 795.01 & $1,192.52$ \\
\hline 2. Variable costs & & & \\
\hline Fingerlings (US\$) & thousand & 23.74 & 23.74 \\
Raw protein feed 28\% (US\$) & US\$/kg & 0.427 & 0.427 \\
Sole weight consumption CAA ${ }^{2}=1: 1$ & US\$ & $8,204.15$ & $16,408.31$ \\
Mix consumption mix-2 CAA = 1.2:1 & US\$ & $9,024.57$ & $18,049.14$ \\
Mix consumption mix-3 CAA $=1.6: 1$ & US\$ & $9,844.98$ & $19,689.97$ \\
\hline
\end{tabular}

decisions as to the weight harvest of the tambaqui species that would be m adequate to the size of the fish farming undertaking. To Pauly et al. (1993) the mathematical model can describe the fish farming system with a precision degree, as per which fish growth and production forecasts can be made. Management of decision and farming can be planned in accordance with economic restrictions and market demand (for instance, fish size and harvest time). The effect of the storage density limit by the DO availability for fish in the pond at each growth stage should be observed, keeping the control over the successive tambaqui growth stages during the cycles, and avoiding DO reduction to a critical level of $3 \mathrm{mg} \mathrm{L}^{-1}$ in the pond (Val \& Almeida-Val, 1995; Gomes et al., 2006). In order to efficiently produce a fish batch, time control of each stage of growth is important following Halachmi's (2007) methodology used in fish farming recirculation system (RAS). Calculations of the time were performed, suggesting the number of days within which a fish batch remains in a specific stage. In our study, these were adjusted to the weight corresponding to those estimated by the growth curve as to the tambaqui weight in a semi-dug pond (Fig.4). The final weight at each stage is like that obtained by Izel \& Melo (2004), Cavero et al. (2009) and Gomes \& Silva (2009).

In the State of Amazonas, small fish farmers have developed with different layout scenarios, in the semiintensive system associated with different costs and resource constraints. The lack of adequate planning for harvesting, and without proper parameter decisionmaking, thus affects the undertaking profitability, and for not having a positive economic turnover, leads to the business discontinuity. Forsberg (1999) in his study with salmon in marine net system claimed that the main problem with harvest planning is to determine the best harvest timing concerning the various fish groups in order to maximize profitability. Simultaneously, the fish farmer should allocate available resources to satisfy, at the same time, market requirements and production restrictions. In our study, the harvest planning to supply cold stores market, supermarkets and street fairs, obtained with the simulation and optimization in the tambaqui biomass production, the highest profitability of US $\$ 9,608$ and US $\$ 15,385$ was that relative to the 10 pond layout scenarios featuring 
harvesting of 0.5 and $1 \mathrm{~kg}$ and $0.5,1$ and $2 \mathrm{~kg}$ target weight mix, respectively.

It should be noted that such results considered stage I fingerlings time equal to that practiced on the farm, that is, 50 days. The results obtained for five pond layout scenarios initially have shown that sole weight of $0.5 \mathrm{~kg}$ harvest is not advantageous; a negative profitability amount (US\$ -949.77), with the quantity of 4,800 fish per pond, that is, a maximum biomass density limited to $2,400 \mathrm{~kg}$ had been verified. The study has demonstrated that the maximum quantity of fish batch can be established with the harvest in different market target weight, in which batches producing larger fish can reach proportional operational profits due to their highest market value (Forsberg, 1999; Hernández et al., 2007; Llorente \& Luna, 2014).

The formulation of an optimization problem with non-linear integer restriction, using an operational research method may not be easy to solve since the objective function should also satisfy an integer linear variable. In our study, an expression has been defined to indicate in the computer simulation the costs accounting relative to 5, 7, and 11 month periods of the production cycle, and incorporated into the objective function. Moreover, it is important to define a binary variable calculated with expression shown Eq. (11):

$$
-C_{f}\left(5+2 t_{2}+6 t_{3}-2 t 2 t_{3}\right), t_{1}, t_{2}, t_{3} \in\{0,1\}
$$

This expression exactly assures the number of months to be counted to deduct the monthly fixed cost $C_{f}$, namely, 5, 7 or 11 months. Thus, by altering some decision parameters ( $S$ : number of days at each phase, c: number of the pond, p: number of sub-batches and $\mathrm{N}$ : fingerlings number), it is possible to obtain values defined in compliance with the needs of the fish farming entrepreneur. More recent studies related to such parameters were conducted in RAS (Halachmi, 2012). However, other studies could bring forth solutions once gaps (time gaps) have been identified between the successive fish growth stages in the pond and can be an alternative for an investigation that can improve the performance of the tambaqui biomass production. Another point for investigation was identified in the time balance calculation between stages, where the days the fish remains in a specific growth stage. Where future studies can establish a better balance of the system, in line with the biology of the species, varying the period in days only at the fingerlings stage proposing a flow of balance between the stages, where the input rate is close to the output rate, that is, $1 / \mu=1 / \lambda$.

\section{CONCLUSIONS}

The mathematical algorithm for the optimization of the target weight mix for the markets has shown the higher profitability of US $\$ 9,608$ and US $\$ 15,385$ for layout 10 ponds, as shown in the Appendix I and II used in simulation modeling. The result obtained in the simulation foresees a simulation of a perfect balance, free from diseases and technical failures, which may result in loss of production batch. The proposed model can be adequate in the introduction of other farmed species, with resource constraints and exposed to environmental conditions and variability which can impact on production. We believe that this algorithm could represent a broad contribution just changing the biological characteristics of the farmed species, which are input data at the algorithm. It is important that, for the use of this methodology, the modeler must obtain information relative to the biology of the species, the growth function, and its statistical distribution of the target weight for the market. Thus, targeting a better efficiency and considering a range determined time for the fingerlings stage, more general models are under construction to aid better decision making.

\section{ACKNOWLEDGMENTS}

The study was funded by the Amazonas state foundation for research Support - FAPEAM and the Federal University of Amazonas (UFAM) aid.

\section{REFERENCES}

Banks, J. 1998. Principles of simulation. In: Banks, J. (Ed.). Handbook of simulation: principles, methodology, advances, applications, and practice. John Wiley \& Sons, New York, pp. 3-30.

Bonet, B. \& Geffner, H. 2005. A probabilistic planner based on heuristic search. Journal of Artificial Intelligence Research, 24(1): 933-944.

Bjørndal, T., Lane, D.E. \& Weintraub, A. 2004. Operational research models and the management of fisheries and aquaculture: a review. European Journal of Operational Research, 156: 533-540.

Barros, A.F. \& Martins, M. 2012. Performance and economic indicators of a large scale fish farming in Mato Grosso, Brazil. Revista Brasileira de Zootecnia, 41: 1325-1331.

Cacho, O.J. 1997. Systems modeling and bioeconomic modeling in aquaculture. Aquaculture Economics \& Management, 1: 45-64. 
Cavero, B.A.S., Rubim, M.A.L. \& Pereira, T.M. 2009. Criação comercial do tambaqui Colossoma macropomum (Cuvier, 1818). Manejo e sanidade de peixes em cultivo. Macapá, 1: 33-46.

Cozman, F.G. 2000. Generalizing variable elimination in Bayesian networks. Workshop on probabilistic reasoning in artificial intelligence. Editora TecArt, São Paulo, pp. 27-32.

Cozman, F.G. 2005. Graphical models for imprecise probabilities. International Journal of Approximate Reasoning, 39(2-3): 167-184.

Corrêa, H.L. \& Corrêa, C.A. 2012. Administração de produção e operações: manufatura e serviços: uma abordagem estratégica. Atlas, São Paulo.

Food and Agriculture Organization (FAO). 2014. The state of food insecurity in the world 2014. Strengthening the enabling environment for food security and nutrition. FAO, Rome.

Forsberg, O.I. 1996. Optimal stocking and harvesting of size-structured farmed fish: a multi-period linear programming approach. Mathematics and Computers in Simulation, 42: 299-305.

Forsberg, O.I. 1999. Optimal harvesting of farmed Atlantic salmon at two cohort management strategies and different harvest operation restrictions. Aquaculture Economics \& Management, 3: 143-158.

Géry, J. 1977. Characoids of the world. T.F.H. Publications, New Jersey.

Graef, E.W. 1995. As espécies de peixes com potencial para criação no Amazonas. In: Val, A.L. \& Honczary, A. (Eds.). Criando peixe na Amazônia. Instituto Nacional de Pesquisas da Amazônia, Manaus, pp. 2943.

Goulding, M. \& Carvalho, M.L. 1982. Life history and management of the tambaqui (Colossoma macropomum, Characidae): an important Amazonian food fish. Revista Brasileira de Zoologia, 12: 107-133.

Gomes, L.C. \& Silva, C.R. 2009. Impact of pond management on tambaqui, Colossoma macropomum (Cuvier), production during growth-out phase. Aquaculture Research, 40: 825-832.

Gomes, L.D., Chagas, E.C., Martins-Junior, H., Roubach, R., Ono, E.A. \& Lourenco, J.N.D. 2006. Cage culture of tambaqui (Colossoma macropomum) in a central Amazon floodplain lake. Aquaculture, 253: 374-384.

Halachmi, I. 2007. Biomass management in re-circulating aquaculture systems using queuing networks. Aquaculture, 262: 514-520.

Halachmi, I. 2012. Mathematical principles of a balanced layout design: Part I. 250-t/year RAS. Aquaculture Engineering, 50: 1-10.
Haji, B. \& Ross, S.M. 2015. M/G/o with exponentially distributed setup times. Operations Research Letters, 43(1): 26-28.

Hillier, G. S. \& Lieberman, G.J. 1988. Introdução à pesquisa operacional. Editora da Universidade de São Paulo, São Paulo.

Hernandez, J.M., Leon-Santana, M., \& Leon, C.J. 2007. The role of the water temperature in the optimal management of marine aquaculture. European Journal of Operational Research, 181(2): 872-886.

Howard, R.A. 1960. Dynamic programming and Markov process. MIT Press, Massachusetts.

Izel, A.C.U. \& Melo, L.A.S. 2004. Criação de tambaqui (Colossoma macropomum) em tanques escavados no Estado do Amazonas. Embrapa Amazônia Ocidental, 32: $20 \mathrm{pp}$.

Jacoby, D.M.P., Brooks, E.J. \& Croft, D.P. 2012. Developing a deeper understanding of animal movements and spatial dynamics through novel application of network analyses. Methods in Ecology and Evolution, 3(3): 574-583.

Knill, O. 1994. Probability and stochastic processes with applications. Overseas Press, Nueva York.

Kubitza, F. \& Kubitza, L.M.M. 2000. Qualidade da água, sistemas de cultivo, planejamento da produção, manejo nutricional e alimentar e sanidade. Panorama da Aqüicultura, 10(59): 44-53.

Krajewski, L., Ritzman, L. \& Malhotra, M. 2009. Administração de produção e operações. Pearson Prentice Hall, New Jersey.

Law, A.M. \& Kelton, W.D. 2000. Simulation modeling and analysis. McGraw-Hill, Boston.

Leung, P.S. \& Shang, J.C. 1989. Modeling prawn production management systems: a dynamic Markov decision approach. Agricultural Systems, 29: 5-20.

Liu, Z. \& Yu, S. 2016. The M/M/C queueing system in a random environment. Journal of Mathematical Analysis and Applications, 436(1): 556-567.

Llorente, I. \& Luna, L. 2014. Economic optimization in seabream (Sparus aurata) aquaculture production using a particle swarm optimization algorithm. Aquaculture International, 22(6): 1837-1849.

Mirande, J.M. 2010. Phylogeny of the family Characidae (Teleostei: Characiformes): from characters to taxonomy. Neotropical Ichthyology, 8(3): 385-568.

Pauly, D., Prein, M. \& Hopkins, K.D. 1993. Multiple regression analysis of aquaculture experiments based on the "extended Gulland-and-Holt plot": model derivation, data requirements and recommended procedures. In: Prein, M., Hulata, G. \& Pauly, D. (Eds.). Multivariate methods in aquaculture research: case studies of tilapias in experimental and commercial systems. International Center for Living 
Aquatic Resources Management, Studies and Reviews, 20, pp. 13-23.

Pidd, M. 1992. Computer simulation in management science. John Wiley \& Sons, Chichester.

Puterman, M.L. 1994. Markov decision processes discrete stochastic dynamic programming. John Wiley $\&$ Sons, New York.

Saint-Paul, U. 1986. Potential for aquaculture of South American freshwater fishes: a review. Aquaculture, 54: 205-240.

Sousa, R.G.C. \& Freitas, C.E.C. 2010. Seasonal catch distribution of tambaqui (Colossoma macropomum), Characidae in a central Amazon floodplain lake: implications for sustainable fisheries management. Journal of Applied Ichthyology, 27: 118-121.

Silva, P.C., Kronka, S.N., Tavares, L.H.S., Sousa, R.P. \& Souza, V.L. 2003. Avaliação econômica da produção da tilápia nilótica em tanques com diferentes trocas de água e densidades populacionais no sistema raceway. Acta Scientiarum, 25(1): 9-13.

Silveira, S.T., Daroit, D.J., Sant'Anna, V. \& Brandelli, A. 2013. Stability modeling of red pigments produced by Monascus purpureus in submerged cultivations with sugarcane bagasse. Food and Bioprocess Technology, 6(4): 1007-1014.

Santos, E.P. 1978. Dinâmica de população aplicada à pesca e piscicultura. Editora Hucitec Edusp, São Paulo.

Santos, E.P., Silva, A.B. \& Lovshin, L.L. 1976. Análise quantitativa em um ensaio de piscicultura intensiva com pirapitinga, Colossoma bidens. Departamento Nacional de Obras Contra as Secas (DNOCS), Boletim Técnico, 34(2): 93-104.

Received: 22 March 2018; Accepted: 15 March 2019
Summerfelt, S.T., Hankins, J.A., Summerfelt, S.R. \& Heinen, J.M. 1993. Modeling continuous culture with periodic stocking and selective harvesting to measure the effect on productivity and biomass capacity of fish culture systems. In: Wang, J.K. (Ed.). Techniques for modern aquaculture: proceedings of an aquacultural engineering conference, 21-23 June 1993, Spokane, WA. American Society of Agricultural Engineers, Michigan, pp. 581-593.

Summerfelt, S.T., Sharrer, M.J., Tsukuda, S.M. \& Gearheart, M. 2009. Process requirements for achieving full-flow disinfection of recirculating water using ozonation and UV irradiation. Aquacultural Engineering, 40: 17-27.

Sparre, P. 1976. A Markovian decision process applied to optimization of production planning in fish farming. Meddelelser fra Danmarks Fiskeri-og Havunders $\varnothing-$ gelser Ny Serie, 7: 111-197.

Teichert-Coddington, D.R. 1996. Effect of stocking ration on semi-intensive polyculture of Colossoma macropomum and Oreochromis niloticus in Honduras, Central America. Aquaculture, 143: 291-302.

Tirdad, A., Grassmann, W. \& Tavakoli, J. 2016. Optimal policies of $\mathrm{M}(\mathrm{t}) / \mathrm{M} / \mathrm{c} / \mathrm{c}$ queues with two different levels of servers. European Journal of Operational Research, 249(3): 1124-1130.

Val, A.L. \& Almeida-Val, V.M.F. 1995. Fishes of the Amazon and their environment: physiological and biochemical features. Springer-Verlag, Heidelberg.

Winston, W.L. 2004. Operations research: applications and algorithms. Brooks Cole, California. 